\title{
A Study on the Precursors for Gastronomic Satisfaction of Tourists in Malaysia
}

\author{
${ }^{1}$ Gunjan Suresh Jaiswal, ${ }^{1}$ Nandita Sapra, ${ }^{1}$ Jyotsna A. Patil, *Neerjang Lama ${ }^{2}$ \\ ${ }^{1}$ LAD \& SRP College of Women, Malaysia \\ 2Universiti Tunku Abdul Rahman, Malaysia \\ *neerjang@utar.edu.my
}

\begin{abstract}
This paper aims to contextualize the idea of food tourism, not only as an attention-grabbing field of research, but in the contention that it can be utilized as a wider theoretical lens to propose a system for rationally identifying preferences of food / gastronomy / culinary tourists. This paper will make an attempt to put forward the insights currently underpinning the latest progress towards a more culturally responsive and critically orientated tourism research. More to the point, this study will be able to facilitate the practitioners to gain insights on the factors affecting satisfaction of tourists which will in turn lead to a boost in visits by foreign tourists to Malaysia. A conceptual framework consisting of 4 independent variables and 1 dependent variable has been proposed. Since there are limited numbers of studies on Gastronomy tourism in Malaysia, there is a need to study this significant topic.
\end{abstract}

Keywords: Customer Satisfaction, Tourism, Culinary, Cuisine, Food Tourism

\section{Introduction}

Tourism is deemed to be one of the most vital export industries (Shahin \& Dabestani, 2010; Yong, Keng, \& Leng, 1993) and it has been both a reason and the recipient of the long-standing period of economic development witnessed in recent decades (George and Alexander, 2012). Tourism is about spaces and places that are rooted in cultures, economies, and social lives of countries and communities (Saila and Mika, 2011). Tourism has provided enjoyment, variety, respite and amusement to innumerable numbers of traveller and holiday makers. Tourism is a commonly recommended solution for regions that have declined economically (Liu and Wall, 2006; Ramjee et al. 2010; Seetanah, 2011). According to Geoffrey Lacher and Chi-Ok Oh (2012) along with carving the path for industrial diversity, tourism puts forward the promise of generating many employment opportunities, and these new jobs possibly will stimulate accelerated economic development. In what went before, tourism has been frequently linked merely to visual, sightseeing or gazing (Urry, 1990). Nevertheless, this predicament and inadequacy have been conceded by several researchers. Consequently Urry (2002) stated that tourism must take account of diverse "sensecapes", such as "tastescapes" and "smellscapes". In the similar line, Everett \& Aitchison (2008) also argued that tourism should be further than just visual gazing and advocates that there should be a place for food tourism within a critical tourism research agenda. Zainal, Zali and Kassim (2010) established that food is an element that characterizes the appeal and charisma of a destination other than the weather, accommodation and striking landscape. Food has a strategic significance in the economy of every country. Concurrently, it has an immense predominance in the institution of a quantitatively and qualitatively satisfactory tourism industry. Food as a marketing device on the macro level has been often disregarded; as the product is mostly perishable, it fluctuates from person to person and disparities are inadequately identified (Boyne, Hall, \& Williams, 2003), however through closer inspection, food tourism holds the impending potential to aid the restoration of several communities, whether they are just beginning to gaze at the tourist market or whether they are institutions and establishments streamlining their marketing strategies.

A country's food can be a decisive aspect of a destination's reflection and this idea has constantly been drawn in advertising as well (Lawrence, Wei-Wen and Yu-Ting, 2012). It has also been revealed that tourists pay out nearly $40 \%$ of their funds on food when travelling (Boyne, Williams, \& Hall, 2002). Thus, food is an important constituent of the tourist product. Besides that, food tourism also profiles gastro destinations such as France, Italy, and California. In developing tourist attractions such as Croatia, Vietnam and Mexico, food portrays a central component of the overall experience (Paul, 2010). The appeal of food to tourists has been documented by destination marketers at a national, regional and local level (Frochot, 2003; Okumus et al., 2006). The availability of good food and an absence of any apprehension concerning food cleanliness have been addressed as a strength and opportunity in the context of food tourism (Joan, 2009). Malaysia and Singapore, as an exemplar, are depicted as 
representative of the multiculturalism in both states where Chinese, Indian, Malay, Eurasian, Western, other cuisines and "fusion" food are all on sale from hawker centres to fine dining (STB, 2005; Tourism Malaysia, 2007). According to Tourism Malaysia (2012), it is imperative to focus the spotlight on ASEAN travellers, as in the year 2011, 42 percent (29.4 million) out of the total 70 million travellers who travel to ASEAN countries are travellers from within ASEAN countries. The Malaysian government has also started to give emphasis to gastronomy tourism in Malaysia. It appears that, culinary tourism which is typically deemed only as a sustaining niche product will now showcase Malaysia's food to be known as "Malaysia Truly a Kitchen" (Zainal, Zali and Kassim, 2010). It is time for the tourism academy to mobilize food tourism out of the 'grey zone' of cultural and traditional tourism and recognize its intangible prospects (Scarpato, 2002). Instituted on these perspectives, one can strongly hold that local and regional food is a strong attribute that can append value to a destination and can add towards well-organized marketing of a destination (du Rand Heath and Albert, 2006).

\section{Literature Review}

Food and tourism enclose an exceedingly close connection. Food is a vital tourism resource (Henderson, 2004; Quan and Wang, 2004). It is essential for physical nourishment which tourists inevitably require while travelling. However food can be a chief and crucial motivator which gratifies a variety of physiological and other needs and wants (Joan, 2009; Tikkanen, 2007). Food consumption in the broad perspective is acknowledged as an anthology of contextual and evolving social customs, (Athena, Margaret, and Anita, 2012) where food no longer merely sets out as provisions but in addition an approach to relate to other people in social, cultural and political terms (Oosterveer, 2006). Hall and Mitchell (2001) define food tourism as "visitation to primary and secondary food producers, food festivals, restaurants and specific locations for which food tasting and / or experiencing the attributes of specialist food production region are the motivating factor for travel" (p. 308). In her book, Exotic Appetites, Lisa Heldke (2003) attributes to gastronomic tourists as "food adventurers" who are on a continuous pursuit for newness in their eating experiences. She elucidates that food lovers are "those people for whom eating is an expedition into the unknown, a pursuit of the strange" (p. xxi). Relying heavily on associations of food as symbolic of geographical or cultural differences, culinary tourism provides opportunities for tourists to "taste" the contrariety. Gastronomic experiences render an important role in shaping perceptions and contentment with the overall travel savoir-faire (Neild et al., 2000; Remmington and Yuksel, 1998) and food apparently demonstrates the power to invade on tourist mind-sets, choices and behavior (Hjalanger and Corigliano, 2000). As regards to gastronomic tourism, Santich (2004) postulates that it is "tourism or travel motivated, at least in part, by an interest in food and drink, eating and drinking" (p. 20). Santich in continuation also affirms that gastronomic tourism is about involving yourself in another culture, connected with a particular place and people.

People are nowadays travelling more for the motives of gastronomy (Bessiere, 1998; Hall \& Sharples, 2003; Long, 2004). As a consequence, food tourism, in its wide-ranging sense, has acquired a superior profile as a pull factor in destination marketing (Boniface, 2003; Cohen \& Evieli, 2004; Hall \& Sharples, 2003; Hjalager \& Richards, 2002). According to (Bendegul, Fevzi \& Bob, 2007) food can render a pivotal role in setting apart destinations in an evocative manner. Since cuisines are 'branded' by nationality; (Chinese, French, Italian, Turkish, Mexican, etc.), the opportunity exists to generate a constructive alliance between a style of food and a destination. Food linked tourism can let tourists accomplish preferred aspirations of recreation, exhilaration, diversion, status, and lifestyle (Frochot, 2003). With deference to food-related matters in destination responsiveness, Sparks et al (2001) and Sparks et al (2003) call attention to the significant contributions a restaurant can put together to a tourism destination. They underline restaurants as a significant constituent of tourist attraction, which may possibly influence tourists' behaviour and overall satisfaction with a destination.

Figure 1.0 is a basic ECSI model which is a structural equation model with latent variables. The model connects customer satisfaction to its driver, and finally to customer loyalty. The drivers for customer satisfaction are perceived image, customer expectations, perceived quality and lastly the value for money. The perceived quality can be divided into (1) hard ware - the quality of the product or service attributes and (2) human ware - customer interactive elements in the service. 


\section{Review of Relevant Theoretical Models}

Figure 1: Relevant Theoretical Model 1

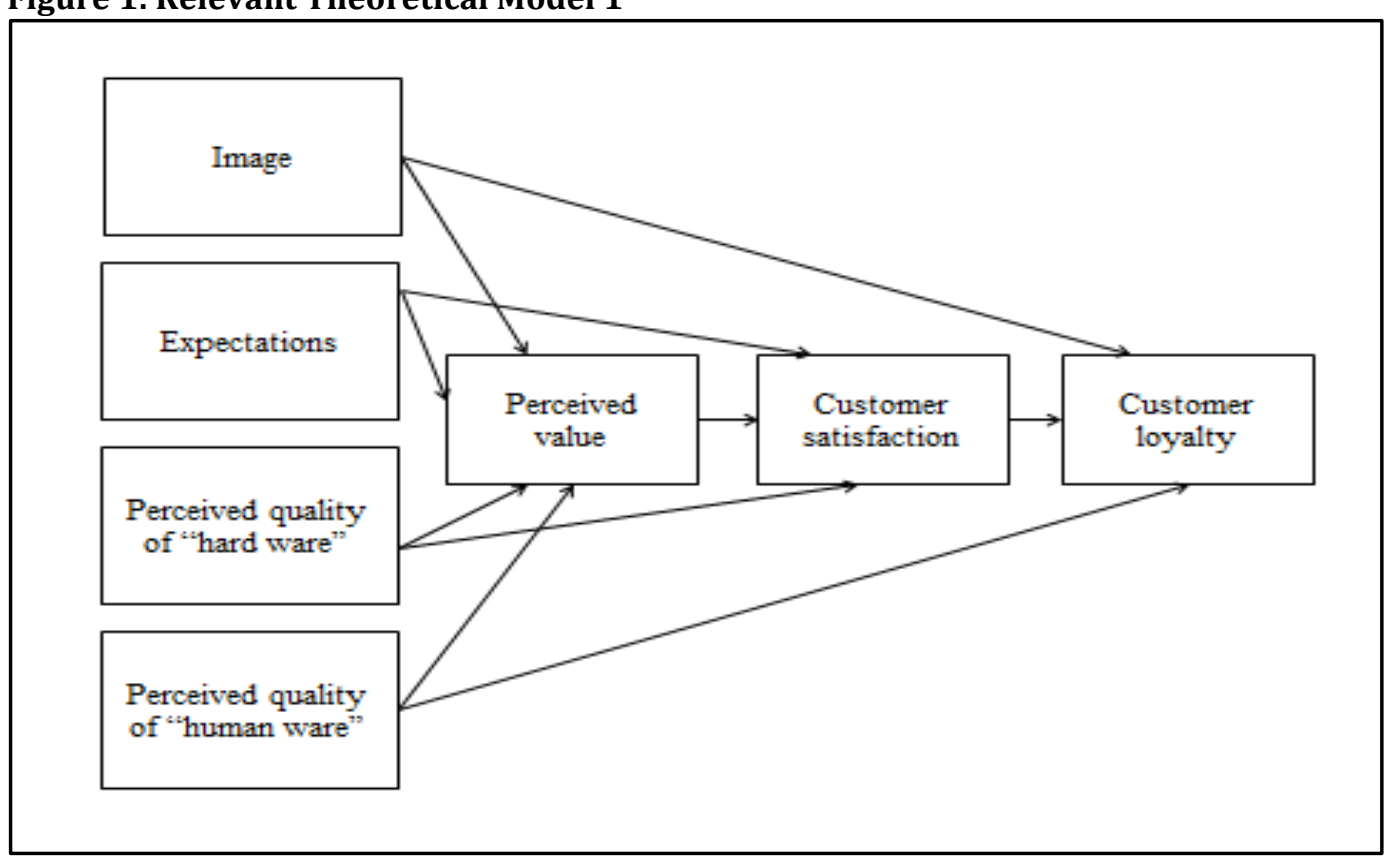

Adopted from: Juhl, H. J., Kristensen, K., \& Ostergaard, P. (2002). Customer satisfaction in European food retailing. Journal of Retailing and Consumer Services, 9, 327-334.

Figure 2: Relevant Theoretical Model 2

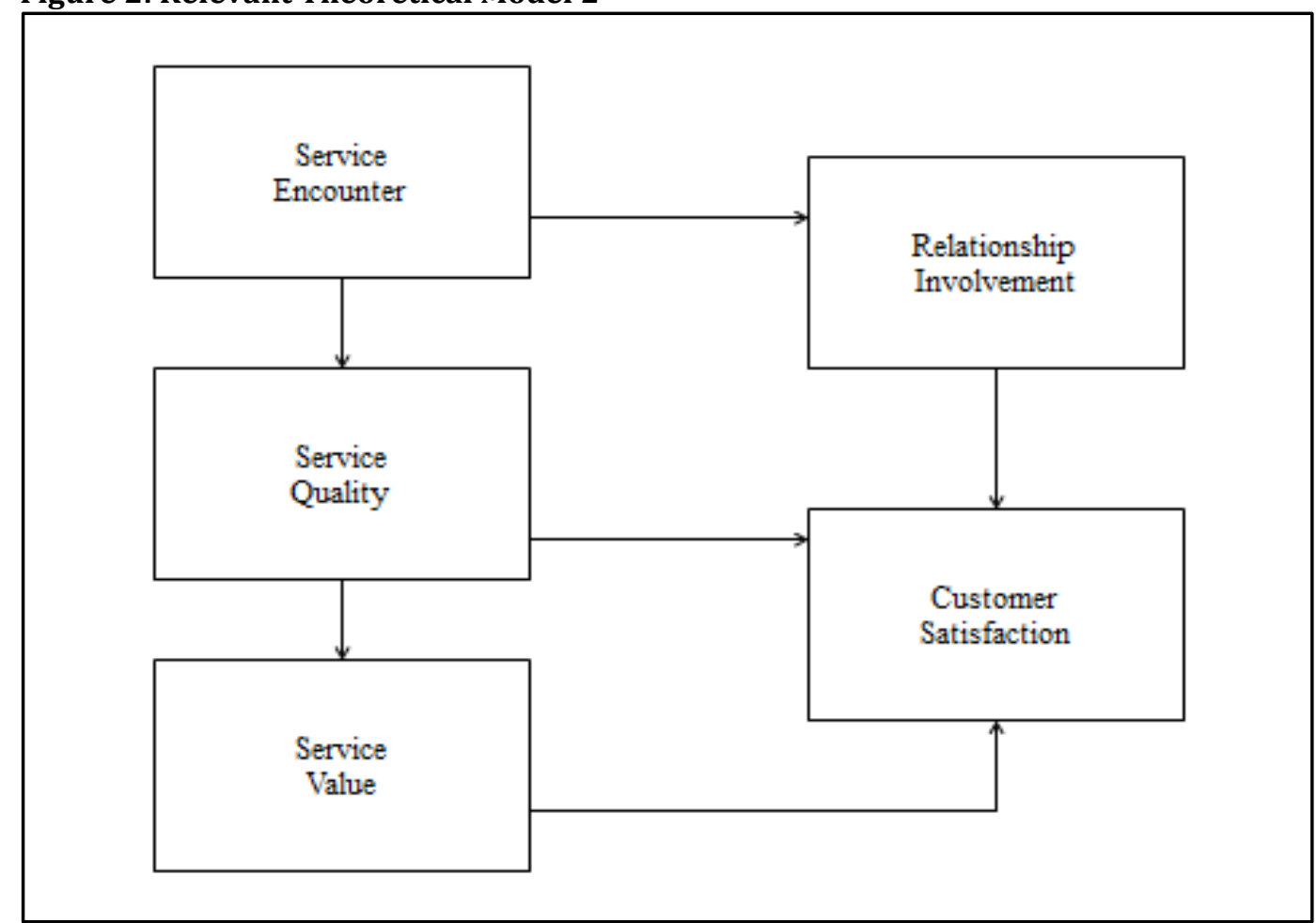

Adopted from: Lin, W. B. (2007). The exploration of customer satisfaction model from a comprehensive perspective. Expert System with Applications, 33, 110-121.

Figure 2 is a customer satisfaction model from a comprehensive perspective of relationship involvement, service encounter, service quality, and service value. 
Independent Variables

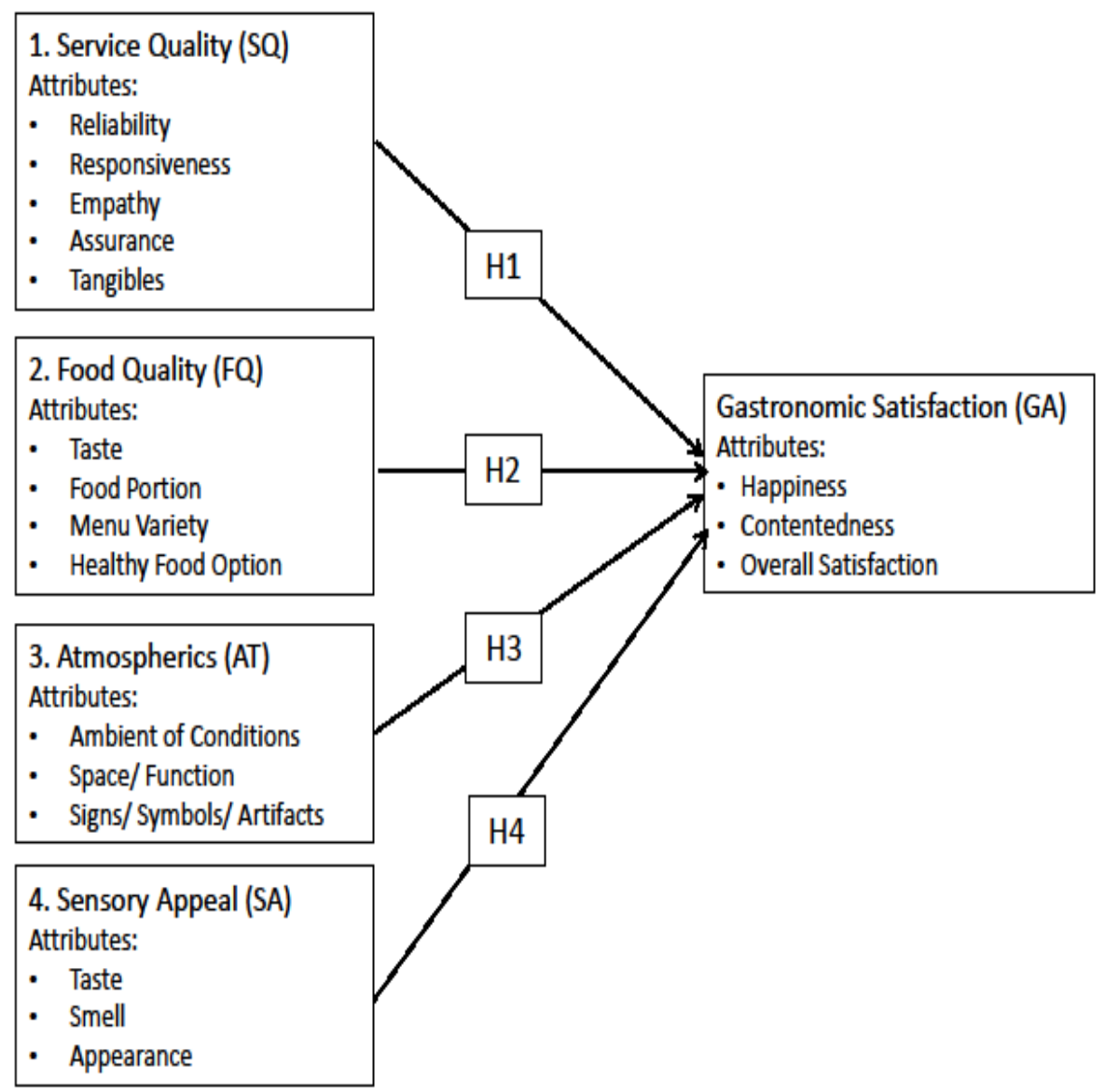

Dependent Variables 
loyalty (Olsen, 2002; Martinez and Martinez, 2010). In the expressions of service quality, research illustrates that a high quality employee service will result in a higher customer satisfaction which will lead to higher levels of affirmative post-consumption behaviour such as revisiting, positive word of mouth or recommending the restaurant to others (Chow et al., 2007; Cronin et al., 2000; Oliver, 1999). Besides service quality, the same pertains to food quality as well. Food quality has been regarded as a main building block of customers' dining experiences which will impinge on the customers' satisfaction which subsequently determines the post behaviours (Kivela et al., 2000; Namkung and Jang, 2007). When customers are satisfied with the gastronomy product (gastronomic satisfaction) it will lead to customer satisfaction. According to Day (1984), customer satisfaction can be characterized as a post purchase evaluative opinion with reference to the purchase decision. Tourist satisfaction has been the focal point of a number of studies (Correia, Moital, Costa and Peres, 2008).

Soderlund and Ohman (2005) examined the function of purchasing intentions as a link involving satisfaction and revisit behaviour. The outcome of the study confirmed that customer satisfaction is decidedly associated to intentions. The unsurpassed theory that elucidates customer satisfaction is the Expectancy-Disconfirmation theory which was pioneered by Lewin (1938). There are three likely situations in this theory: (1) confirmation occurs when actual performance matches expectations; (2) positive disconfirmation occurs when actual performance exceeds expectation which in turns lead to satisfaction; and lastly (3) negative disconfirmation occurs when actual performance is of poorer quality than expected which results in dissatisfaction. This approach to customer satisfaction is purely based on cognitive process of expectations (Oliver, 1980, 1989). On the other hand, researchers assume that merely considering the cognitive aspect may prove insufficient. As a consequence, by bringing into play the performance-based approach, scores of studies persisted to integrate cognitive judgments and affective reactions (Lin, 2004; Mano and Oliver, 1993; Westbrook and Oliver, 1991). According to Ha and Jang (2010), customer satisfaction is viewed as a cognitive assessment of service or food quality and affective aspects brought in through by consumption experiences.

Service Quality: Service quality is defined as consumers' perceptions or subjective judgments of a service's overall excellence or superiority (Aaker and Jacobson, 1994). However, a consumer's subjective judgment of quality can be influenced by the personal service experiences, unique needs, as well as consumption situations (Palmer, 2005). Service quality unlike product quality is difficult to measure due to its inherently abstract and elusive characteristics (Parasuraman etal., 1988). There are two perspectives for service quality: (1) The customer's cognitive evaluation of the service provided (Taylor and Baker, 1994); (2) Multidimensional construct created by an evaluation of attribute performance (Parasuraman et al., 1988). Service quality can be measured using SERVQUAL which was developed by Parasuraman et al. (1988). It consists of five dimensions: Reliability, Responsiveness, Empathy, Assurance, and Tangibles. SERVQUAL has been applied in several studies to assess service quality in service-related situations (Caruana et al., 2000; Lee and Lambert, 2000). However, according to Nam and Lee (2011), there are many researchers (e.g., Carmen, 1990; Ekinci et al., 1998; Para suraman et al., 1994) thinks that not all dimensions are necessary. According to Nikolich and Sparks (1995), the perceived levels of service in restaurants are based on the relationship between customers and service providers thus in this study, service quality will refers to the level of service provided by the restaurant employees.

Food Quality: Food quality is one of the most critical components of a dining experience (Namkung and Jang, 2007; Sulek and Hensley, 2004). Clark and Wood (1999) found that food quality is one of the major factors that influence customer loyalty in restaurant choice. Besides that, Susskind and Chan (2000) states food quality is a key determinant for visiting a restaurant from the customer's perspective and Mattila (2001) consider food quality as a key predictor of customer loyalty in casual-dining restaurants. Food quality is the most important element of customer satisfaction when it is compared with other aspects of the restaurant. Recently, a positive relationship between food quality and satisfaction or behavioral intentions is tested and found by Namkung and Jang (2007). Food quality can be measured by using several attributes. According to Kivela et al. (2000), the attributes of food quality comprises of tastiness of food, menu variety, and nutrition to examine the effect of excellent food on customer satisfaction and revisit intentions. On the other hand, Raajpoot (2002) uses food presentation, serving size, menu design, and variety of food to measure food quality in the foodservice industry while Namkung and Jang (2007) took presentation, menu item variety, healthy options, taste, freshness, and temperature to judge food quality. According to Sulek and Hensley (2004), there are three general food characteristics that determine the quality: safety, appeal, and dietary acceptability. 
Sensory Appeal: According to Yoon and Park (2011), human senses are powerful and incredible information collection system. From that information, ones' able to create and recreate images of surrounding situations and intuitively and instantaneously process the sensory information to make forthcoming decisions. According to Lindstrom (2005), the studies between sensory appeals and brand effectiveness suggests that consumer brand loyalty results from sensory perceptions of superior brand experience, leadership, as well as clarity. Besides that, the study also shows that all five senses (taste, smell, sight, sound, and touch) have different stages of impact on loyalty. The greatest influence is taste, followed by smell, sound, touch, and sight. Yoon and Park (2011) also suggest that the five senses play an important part in assisting us understanding the world by recalling the resident information stored in our memories, thus, sensory system is important in encoding, retrieving, and reconstructing information. In tourism setting, sensory can be one of the motives in food selection (Lau, Krondl, \& Coleman, 1984; Rappaport Peters, Huff-Corzine, \& Downey, 1992; Bell \& Marshalls, 2003). Besides that, the Food Choices Questionnaire (Steptoe et al., 1995) and the Food Motivations Scale (Martins \& Pliner, 1998), suggest that sensory factor is one of the motivations underlying individuals' everyday food choices. Study done by Laureati, Pagliariani, Calcinoni and Bidoglio (2006) found that the most important senses during food consumptions is taste and followed by smell and appearance of food. Susheela (1998) claimed that tasty food will leads the consumers to indulge in tasty food and allow the consumers to experience the variety of local food with different herbs and spices. Besides that, Kim et al. (2009), shows that the appearance of local food such as well displayed and good cooking performance is a motivational factor in providing sensory pleasure to tourists. Dann and Jacobsen (2002) concluded that the sensory experience can be satisfied through the smell and taste of local food during ones' visitation to a destination.

\section{Discussions}

First and foremost, building and projecting positive and favorable food image for tourist's minds is considered as vital element in promoting Malaysian food worldwide and generating their behaviors owing to the image has been proved to be an imperative element in the selection of a destination for ideal vacation. Food tourism offers a conceptual means of expression to tail a more culturally conscious tourism schema. The rationale of this paper is to consider the inputs of food with particular indication to the magnitude of food tourism and the dynamics which are crucial to its accomplishment. People are now travelling for motives of gastronomy. Food and beverage can form one of the most vital elements of a country's economy as food tourism emerges to be flourishing with tremendous prospects. This research offers an insight and enhanced understanding into a number of refined and practical propositions for practitioners and policy makers on the antecedent contributing to gastronomic satisfaction so that they can plan appropriate strategies that satisfy needs and wants of foreign tourists in Malaysia. This research provides an insight on several refined and practical implications for practitioners and policy makers. The results of this study can assist managers in order to have a better understanding on the antecedent contributing to gastronomic satisfaction so that they manage to project suitable strategies that satisfy tourist's needs and wants.

Probable Limitations of the Study: Firstly this study will be limited to gastronomic satisfaction in Malaysia. The results therefore arrived at, may not be adequate to generalize the perspectives of other countries especially the Western countries. This is owing to the differences in cultural settings and service offerings existing between Malaysia and the rest of the world. Secondly, the study will have its main focus on gastronomic satisfaction. Other aspects of tourism would not be directly covered and hence a holistic approach would not be attained, as relevancy and reliability of findings may be hampered across other dimensions of the service industry, particularly tourism. Thirdly, incomplete or manipulated information would be another concern while collecting questionnaires. Respondents may not be willing to provide precise and accurate information beyond their comfort zone which in their opinion may be personal especially when they have to provide the information in black and white. It cannot be denied that these limitations are well-acknowledged; yet, they will not detract from the significance of findings but merely provide new platforms for future research. 


\section{References}

Aaker, D. A. \& Jacobson, R. (1994). The financial information content of perceived quality. Journal of Marketing Research, 31(2), 191-201.

Athena, H. N. M., Margaret, L., Anita, E. (2012). Globalisation and food consumption in tourism. Annals of Tourism Research, 39(1), 171-196.

Baker, J., Grewal, D. \& Parasuraman, A. (1994). The influence of store environment on quality inferences and store image. Journal of the Academy of Marketing Science, 22(4), 328-339.

Bell, R. \& Marshall, D. W. (2003). The construct of food involvement in behavioral research: Scale development and validation. Appetite, 40, 235-244.

Bendegul, O., Fevzi, O., Bob, M. (2007). Incorporating local and international cuisines in the marketing of tourism destinations: The cases of Hong Kong and Turkey. Tourism Management, 28(1), 253-261.

Bessiere, J. (1998). Local development and heritage: Traditional food and cuisine as tourist attractions in rural areas. Sociologia Ruralis, 38(1), 21-34.

Boniface, P. (2003). Tasting tourism: Travelling for food and drink. Burlington: Ashgate Publishing.

Boyne, S., Hall, D. \& Williams, F. (2003). Policy, support and promotion for food-related tourism initiatives: A marketing approach to regional development. Journal of Travel \& Tourism Marketing, 14(3), 131-154.

Boyne, S., Williams, F. \& Hall, D. (2002). On the Trail of Regional Success: Tourism, Food Production, and the Isle of Arran Taste Trail. In Tourism and Gastronomy, edited by A-M. Hjalager and G. Richards. London: Routledge, 91-114.

Carmen, J. M. (1990). Consumer perceptions of service quality: an assessment of the SERVQUAL dimensions. Journal of Retailing, 66(1), 33-55.

Caruana, A., Money, A. H. \& Berthon, P. R. (2000). Service quality and satisfaction- the moderating role of value. European Journal of Marketing, 34(11/12), 1338-1352.

Chow, I. H., Lau, V. P., Lo, T. W., Sha, Z. \& Yun, H. (2007). Service quality in restaurant Operations in China: decision- and experiential-oriented perspectives. International Journal of Hospitality Management, 26(3), 698-710.

Clark, M. A. \& Wood, R. C. (1999). Consumer loyalty in the restaurant industry: a preliminary exploration of the issues. British Food Journal, 101(4), 317-326.

Cohen, E. \& Evieli, N. (2004). Food in tourism: Attraction and impediment. Annals of Tourism Research, 31(4), 755-778.

Correia, A., Moital, M., Da-Costa, C. F. \& Peres, R. (2008). The determinants of gastronomic tourists' satisfaction: a second-order factor analysis. Journal of foodservice, 19, 164-176.

Cronin, J. J., Brady, M. K. \& Hult, G. T. M. (2000). Assessing the effects of quality, value, and customer satisfaction on consumer behavioral intentions in service environments. Journal of Retailing, 76(2), 193-218.

Dann, G. M. \& Jacobsen, J. K. (2002). Leading the tourist by the nose. In: Dann, G. M. (Ed.), the Tourist as a Metaphor of the Social World. CABI Publishing, New York, 209-236.

Day, R. L. (1984). Modelling choices among alternative responses to dissatisfaction. Advances in Consumer Research, 11, 496-499.

Du-Rand, G. E. \& Heath, E. (2006). Towards a framework for food tourism as an element of destination marketing. Current Issues in Tourism, 9(3), $206-234$.

Ekinci, Y., Riley, M. \& Fife-Schaw, C. (1998). Which school of thought? The dimensions of resort hotel quality. International Journal of Contemporary Hospitality Management, 10(2/3), 63-67.

Everett, S. \& Aitchison, C. (2008). The role of food tourism in sustaining regional identity: A case study of Cornwall, south west England. Journal of Sustainable Tourism, 16(2), 150-167.

Frochot, I. (2003). An analysis of regional positioning and its associated food images in French tourism regional brochures. Journal of Travel and Tourism Marketing, 14(3/4), 77-96.

Geoffrey, R. L. \& Chi-Ok, O. (2012). Is Tourism a Low-Income Industry? Evidence from Three Coastal Regions. Journal of Travel Research, 51(4,) 464-472.

George, A. A. \& Alexander, J. (2012). Identifying and Ranking the Determinants of Tourism Performance: A Global Investigation. Journal of Travel Research, 51(4), 388-399.

Hall, C. M. \& Mitchell, R. (2001). Wine and food tourism. In: N. Douglas, N. Douglas and R. Derrett (eds.) Special Interest Tourism: Context and Cases. New York, NY: John Wiley and sons, 307 - 329.

Hall, M. \& Sharples, L. (2003). The consumption of experiences or the experience of consumption? An introduction to the tourism of taste. In M. Hall, L. Sharples, R. Mitchell, N. Macionis, \& B. 
Cambourne (Eds.), Food tourism around the world: Development, management and markets. Oxford: Butterworth-Heinemann.

Ha, J. \& Jang, S. C. (2010). Effects of service quality and food quality: The moderating role of atmospherics in an ethic restaurant segment. International Journal of Hospitality Management, 29, 520-259.

Heldke, L. (2003). Exotic appetites. London: Routledge.

Henderson, J. C. (2004). Food as a tourism resource: a view from Singapore. Tourism Recreation Research, 29(3), 69-74.

Hjalanger, A. M. \& Corigliano, M. A. (2000). Food for tourists: determinants of an image. International Journal of Tourism Research, 2(4), 281-93.

Hjalager, A. \& Richards, G. (Eds.). (2002). Tourism and gastronomy. London: Routledge.

Joan, C. H. (2009). Food tourism reviewed. British Food Journal, 111(4), 317-326.

Juhl, H. J., Kristensen, K. \& Ostergaard, P. (2002). Customer satisfaction in European food retailing. Journal of Retailing and Consumer Services, 9, 327-334.

Kim, Y. G., Eves, A. \& Scarles, C. (2009). Building a model of local food consumption on trips and holidays: A grounded theory approach. International Journal of Hospitality Management, 28, 423-431.

Kivela, J., Inbakaran, R. \& Reece, J. (2000). Consumer research in the restaurant environment. Part 3. Analysis, findings and conclusions. International Journal of Contemporary Hospitality Management, 12(1), 13-30.

Lau, D., Krondl, M. \& Coleman, P. (1984). Psychological factors affecting food selection. In J. Galler (Ed), Nutrition and behavior (397-415).

Laureati, M., Pagliarini, E., Calcinoni, O. \& Bidoglio, M. (2006). Sensory acceptability of traditional food preparations by elderly people. Food Quality and Preferences, 17, 43-52.

Lawrence, W. L., Wei-Wen, W., Yu-Ting, L. (2012). Promoting Food Tourism with Kansei Cuisine Design. Procedia - Social and Behavioral Sciences, 40, 609- 615.

Lee, W. \& Lambert, C. U. (2000). Impact of waiting time on evaluation of service quality and customer satisfaction in foodservice operations. Foodservice Research International, 12, 241-254.

Lewin, K. (1938). The Conceptual Representation and Measurement of Psychological Forces. Nurham: Duke University Press.

Lin, I. Y. (2004). Evaluating a servicescape: the effect of cognition and emotion. International Journal of Hospitality Management, 23(2), 163-178.

Lin, W. B. (2007). The exploration of customer satisfaction model from a comprehensive perspective. Expert System with Applications, 33, 110-121.

Lindstrom, M. (2005). Brand Sense: Build Powerful Brands through Touch, Taste, Smell, Sight, and Sound. New York: Free Press.

Liu, A. \& Geoffrey, W. (2006). Planning Tourism Employment: A Developing Country Perspective. Tourism Management, 27(1), 159-70.

Mano, H. \& Oliver, R. L. (1993). Assessing the dimensionality and structure of the consumption experience: evaluation, feeling, and satisfaction. Journal of Consumer Research, 20, 451-466.

Martinez, J. A. \& Martinez, L. (2010). Some insights on conceptualizing and measuring service quality. Journal of Retailing and Consumer Services, 17, 29-42.

Martins, Y. \& Pliner, P. (1998). The development of the food motivation scale. Appetite, 30, 94.

Mattila, A. S. \& Wirtz, J. (2001). Congruency of scent and music as a driver of in-store evaluations and behavior. Journal of Retailing, 77, 273-289.

Namkung, Y. \& Jang, S. (2007). Does food quality really matter in restaurant: its impact of customer satisfaction and behavioral intentions? Journal of Hospitality and Tourism Research, 31(3), 387410.

Nam, J. H. \& Lee, T. J. (2011). Foreign travellers' satisfaction with traditional Korean restaurants. International Journal of Hospitality Management, 30, 982-989.

Neild, K., Kozak, M. \& LeGrys, G. (2000). The role of food service in tourist satisfaction. International Journal of Hospitality Management, 19(2), 375-84.

Nikolich, M. A. \& Sparks, B. A. (1995). The hospitality service encounter: the role of communication. Journal of Hospitality and Tourism Research, 19(2), 43-56.

Okumus, B., Okumus, F. \& McKercher, B. (2006). Incorporating local and international cuisines in the marketing of tourism destinations: the cases of Hong Kong and Turkey. Tourism Management, 28, 253-61.

Oliver, R. L. (1980). A cognitive model of the antecedents and consequences of satisfaction decision. Journal of Marketing Research, 17, 460-469.

Oliver, R. L. (1999). Whence consumer loyalty? Journal of Marketing, 63(4), 33-44. 
Oliver, R. L. (1989). Processing of the satisfaction response in consumption: a suggested framework and research propositions. Journal of Consumer Satisfaction, Dissatisfaction and Complaining Behavior, $2,1-6$.

Olsen, S. 0. (2002). Comparative evaluation and the relationship between quality, satisfaction, and repurchase loyalty. Journal of the Academy of Marketing Science, 30(3), 240-249.

Oosterveer, P. (2006). Globalization and sustainable consumption of shrimp: consumers and governance in the global space of flows. International Journal of Consumer Studies, 30(5), 465-476.

Palmer, A. (2005). Principles of Services Marketing. London: McGraw-Hill.

Parasuraman, A., Zeithaml, V. A. \& Berry, L. L. (1988). SERQUAL: A multiple-item scale for measuring consumer perceptions of service quality. Journal of Retailing, 64, 12-37.

Paul, S. S. (2010). Metropolitan Cuisine Tourism: Exploring Food Tourists to the Creole Cuisine in New Orleans, LA USA. A Thesis Presented in Partial Fulfilment of the Requirements for the Degree Master of Arts. Arizona State University.

Parasuraman, A., Zeithaml, V. A. \& Berry. L. L. (1994). Alternative scales for measuring service quality: a comparative assessment based on psychometric and diagnostic criteria. Journal of Retailing, 70 (3), 193-199.

Quan, S. \& Wang, N. (2004). Towards a structural model of the tourist experience: an illustration from food experiences in tourism. Tourism Management, 5(2), 297-305.

Raajpoot, N. A. (2002). A multiple item scale for measuring tangible quality in foodservice industry. Journal of Foodservice Business Research, 5(2), 109-127.

Ramjee-Singh, D., Wright, A., Hayle, C. \& Craigwell, R. (2010). Is the Tourism-Led Growth Thesis Valid? The Case of the Bahamas, Barbados, and Jamaica. Tourism Analysis, 15(4), 435-45

Rappaport, L., Peters, G., Huff-Corzine, L. \& Downey, R. (1992). Reasons for eating: An exploratory cognitive analysis. Ecology of Food and Nutrition, 28, 171-189.

Reimer, A. \& Kuehn, R. (2005). The impact of servicescape on quality perception. European Journal of Marketing, 39(7/8), 785-808.

Remmington, M. \& Yuksel, A. (1998). Tourist satisfaction and food service experience: results of an empirical investigation. Anatolia, 9(1), 37-57.

Saila, S. \& Mika, K. (2011). Problematizing the Concept of Tourism Destination: An Analysis of Different Theoretical Approaches. Journal of Travel Research, 50(2), 133-143.

Santich, B. (2004). The study of gastronomy and its relevance to hospitality education and training. International Journal of Hospitality Management, 23(1), 15 - 24.

Scarpato, R. (2002). Sustainable Gastronomy as a Tourist Product', pp. 132-51 in Hjalager and G. Richards (eds) Tourism and Gastronomy. London: Routledge.

Seetanah, B. (2011). Assessing the Dynamic Economic Impact of Tourism for Island Economies. Annals of Tourism Research, 38(1), 291-308.

Shahin, A. \& Dabestani, R. (2010). Correlation Analysis of Service Quality Gaps in a Four-Star Hotel in Iran. International Business Research, 12(3), 22-35.

Soderlund, M. \& Ohman, N. (2005). Assessing behaviour before it becomes behaviour: an examination of the role of intentions as a link between satisfaction and repatronizing behaviour. International Journal of Service Industry Management, 16(2), 169-185.

Sparks, B. A., Wildman, K. L. \& Bowen, J. T. (2001). Restaurants as a contributor to tourist destination attractiveness. Australian Journal of Hospitality Management, 8(2), 17 - 30.

Sparks, B., Bowen, J. \& Klag, S. (2003) Restaurants and the tourist market. International Journal of Contemporary Hospitality Management, 15(1), 6 - 13.

STB. (2005). Let's Makan, Singapore Tourism Board, Singapore.

Steptoe, A., Pollard, T. M. \& Wardle, J. (1995). Development of a measure of the motives underlying the selection of food: The Food Choice Questionnaire. Appetite, 25(3), 267-284.

Sulek, J. M. \& Hensley, R. L. (2004).The relative importance of food, atmosphere, and fairness of wait. Cornell Hotel and Restaurant Administration Quarterly, 45(3), 235-247.

Susheela, U. (1998). Food Product Design: New Ethnic entrees. Northbrook: Weeks Publishing Co.

Susskind, A. M. \& Chan, E. K. (2000). How restaurant features affect check averages. Cornell hotel and restaurant Administration Quarterly, 41(6), 56-63.

Taylor, S. A. \& Baker, T. L. (1994). An Assessment of the Relationship between Service Quality and Customer Satisfaction in the Formation of Consumers' Purchase Intentions. J. Retailing, 70(2), 163 - 178.

Tikkanen, I. (2007). Maslow's hierarchy and food tourism in Finland: five cases. British Food Journal, 109(9), 721-34. 
Tourism Malaysia. (2007). Food, Tourism Malaysia, and Kuala Lumpur, available at: www.travel.tourism.gov.my

Tourism Malaysia. (2012). Intra-regional tourism is a lucrative business for all ASEAN countries, [Press Release]. Malaysia: Ministry of Tourism Malaysia.

Urry, J. (1990). The Tourist Gaze: Leisure and Travel in Contemporary Societies. London: Sage.

Urry, J. (2002). The Tourist Gaze (2nd ed.). London: Sage.

Wall, E. A. \& Berry, L. L. (2007). The combined effects of the physical environment and employee behavior on customer perception of restaurant service. Cornell Hotel and Restaurant Administration Quarterly, 48(1), 59-69.

Westbrook, R. A. \& Oliver, R. L. (1991). The dimensionality of consumption emotion patterns and consumer satisfaction. Journal of Consumer Research, 18, 84-91.

Yong, Y. W., Keng, K. A. \& Leng, T. L. (1993). A Delphi Forecast for the Singapore Tourism Industry: Future Scenario and Marketing Implications. International Marketing Review, 20(2), 10-29.

Yoon, S. J. \& Park, J. E. (2011). Do sensory ad appeals influence brand attitude? J Bus Res (2011), doi:10.1016/j.jbusres.2011.02.037

Zainal, A., Zali, A. N. \& Kassim, M. N. (2010). Malaysian gastronomy routes as a tourist destination. Journal of Tourism, Hospitality and Culinary Arts, 2, 15-24. 